\title{
EFFECTS ON DIVALENT CATIONS OF A HAEMODILUTION TECHNIQUE USING ACD BLOOD IN PAEDIATRIC PATIENTS UNDERGOING BYPASS OPEN-HEART OPERATIONS`
}

\author{
A.E. Johnston, M.D., F.M.C.P.(c), \\ L.C. RADDE, M.D., PH.D., F.R.C.P.(C), \\ H.I.A. NISBET, M.B., CH.B., F.R.A.R.C.S.(ENG.), G.R.C.P.(C), \\ AND J. TAYLOR, B.SC.
}

\begin{abstract}
MULTIPLE DERANCEMENTS OF CATION HOMEOSTASIS have been reported with the use of haemodilution techniques in patients undergoing open-heart surgery with cardiopulmonary bypass. ${ }^{1-5}$ However, there have been few reports on alterations in ionic calcium ${ }^{6,7}$ or magnesium, in particular when relatively large volume acid citrate dextrose blood primes are used in children. This has special relevance in view of the chelating effect of citrate on both calcium and magnesium ions. ${ }^{8,0} \mathrm{It}$ is the ionized fractions of calcium and magnesium which determine their effect on cell membrane stability, myocardial contractility, and on the central and peripheral nervous system as well as on skeletal and smooth musculature. ${ }^{10-14}$

The present report deals with plasma and urinary changes in divalent cations occurring in paediatric patients undergoing open-heart operation with cardiopulmonary bypass in which ACD or heparinized blood primes were diluted with 5 per cent glucose in 0.2 per cent sodium chloride.
\end{abstract}

\section{A. Patients}

\section{Materials and Methods}

Twenty-four patients were assigned to three groups according to the type of blood used in the prime. Group A: ACD blood with $5 \mathrm{ml}$ of 10 per cent calcium gluconate added per unit of blood ( $40 \mathrm{mg}$ elemental $\mathrm{Ca}$ ); Group B: ACD blood with $5 \mathrm{ml}$ of 10 per cent $\mathrm{CaCl}_{2}$ added per unit of blood ( $182 \mathrm{mg}$ elemental $\mathrm{Ca}$ ); and Croup $\mathrm{C}$ : Heparinized blood. In Table I the age and body weight of the patients and the duration of cardiopulmonary bypass in each group are summarized.

Five patients each in Groups A and B underwent total correction of tetralogy of Fallot. Group A also included four patch closures of atrial septal defect (ASD) and Group B included three such patients as well as one patch closure of ventricular septal defect (VSD) and one mitral valve replacement. Group $C$ in

- From the Departments of Anaesthesia and Paediatric Research, The Research Institute, The Hospital for Sick Children, Toronto, Canada.

This work was supported in part by the Medical Research Council of Canada (Crant \#MA4386).

Portions of data in paper were presented at the Canadian Anaesthetists" Society Meeting, Quebec City, June 1971. 
TABLE I

Patient Groups

MeAN (RANGE)

\begin{tabular}{|c|c|c|c|}
\hline & $\begin{array}{c}\text { Group A } \\
\text { ACD + Ca gluconate }\end{array}$ & $\begin{array}{c}\text { Group B } \\
\mathrm{ACD}+\mathrm{CaCl}_{2}\end{array}$ & $\begin{array}{c}\text { Group C } \\
\text { heparinized }\end{array}$ \\
\hline $\begin{array}{l}\text { No. of patients } \\
\text { Age (years) } \\
\text { Weight (kg) } \\
\text { Duration of CPB (min) }\end{array}$ & $\begin{array}{c}9 \\
9.2(6-15) \\
27.9(18.6-49.7) \\
72(20-126)\end{array}$ & $\begin{array}{c}10 \\
8.9(5-15) \\
23.2(16.7-44.0) \\
71.5(15-141)\end{array}$ & $\begin{array}{l}5 \\
3.0(2-5) \\
13.5(11.3-17.8) \\
59(41-97)\end{array}$ \\
\hline$\frac{\text { Volume of prime }(\mathrm{ml})}{\text { EBV* of patient }^{*}}$ & $0.8-1.6$ & $0.9-1.5$ & $1.3-2.1$ \\
\hline $\begin{array}{l}\text { Volume of } 5 \% \text { glucose } \\
\text { in } 0.2 \% \mathrm{NaCl}(\mathrm{ml} / \mathrm{kg}) \\
\text { added as diluent }\end{array}$ & $39(38-45)$ & $39(34-42)$ & $49\langle 44-60\rangle$ \\
\hline
\end{tabular}

"EBV =- Estimated blood volume (m)).

cluded two patients who underwent Mustard procedures for correction of transposition of the great vessels, two patch closures of VSD and one patch closure of an ASD.

\section{B. Perfusion Technique and Haemodilution Procedure}

A Temptrol disposable bubble oxygenator ${ }^{*}$ was used in conjunction with a pumping head with a double occlusive roller. ${ }^{\circ}$ The oxygenator is available in three sizes. Table II gives weight ranges of the patients, the total priming volumes and the range of flow rates which were used for each size during the study. The

TABLE II

Sizes of "Temptrol" Disposable Blood Oxygenator

\begin{tabular}{cccc}
\hline \hline Size & $\begin{array}{c}\text { Weight of } \\
\text { patients* }\end{array}$ & $\begin{array}{c}\text { Priming } \\
\text { volumes used* }\end{array}$ & Flow rate* \\
\hline "Infant" & $<10 \mathrm{~kg}$ & $900 \mathrm{ml}$ & up to $1200 \mathrm{ml} / \mathrm{min}$ \\
"Paediatric" & $10-20 \mathrm{~kg}$ & $1800 \mathrm{ml}$ & up to $3400 \mathrm{ml} / \mathrm{min}$ \\
"Adult" & $>20 \mathrm{~kg}$ & $2800 \mathrm{ml}$ & up to $4500 \mathrm{ml} / \mathrm{min}$ \\
\hline
\end{tabular}

*The weight ranges of patients, priming volumes and flow rates shown were those used at the Hospital for Sick Children, Toronto, during the period of the study.

flow rates were based on a cardiac index of 2.4 to $3.11 / \mathrm{min} / \mathrm{m}^{2}$ body surface depending on the size of the patient. The proportionate relationship between the priming volume and estimated blood volume (EBV) of the patients in each group is seen in Table I. The electrolyte and acid base balance is affected by the relationship between volume of prime and estimated blood volume as well as the composition of the diluent. ${ }^{3}$

- Bentley Sales Inc, 180 Main St, Norwalk, Conn. 06851, U.S.A.

- 'Sarns Inc., 6200 Jackson Rd., Ann Arbor, Mich. 48103, U.S.A. 
It is difficult in children to establish comparable degrees of haemodilution because the same priming volumes are used over relatively wide weight ranges (Table II). For example, the same $1800 \mathrm{ml}$ priming volume is used for children weighing 10 or $20 \mathrm{~kg}$. The method chosen to standardize haemodilution was to add the volume of 5 per cent dextrose in 0.2 per cent $\mathrm{NaCl}$ to the prime which would give an overall haemodilution of 30 per cent in the combined volume of the pump prime and the patient's blood volume:

$$
\frac{\text { Volume of diluent }}{\text { EBV }+ \text { pump priming volume }} \times 100=30 \% \text {, }
$$

where the diluent consists of the combined volume of 5 per cent dextrose in 0.2 per cent $\mathrm{NaCl}, \mathrm{ACD}$ solution (USP formula $\mathrm{A}$ ), calcium solution, heparin and THAM. Table I shows this volume of 5 per cent glucose in 0.2 per cent saline expressed in $\mathrm{ml} / \mathrm{kg}$ body weight for the three groups. In each group the initial haematocrit during cardiopulmonary bypass was approximately 30 per cent and the volume of diluent was below the daily fluid requirement for children of the same size.

Fresh ACD blood collected the previous day was used and contained $70 \mathrm{ml}$ ACD solution (USP formula A) per $500 \mathrm{ml}$ unit. We added $35 \mathrm{ml}$ of $0.6 \mathrm{M}$ THAM to each unit of ACD blood and $14 \mathrm{ml}$ to each unit of heparinized blood. Each unit of ACD blood was converted by the addition of $20 \mathrm{mg}$ of sodium heparin $(2 \mathrm{ml})$ and $5 \mathrm{ml}$ of the respective calcium solution. In the past we had routinely added $5 \mathrm{ml}$ of 10 per cent calcium gluconate per unit of blood, the amount recommended to maintain total calcium levels in the normal range during exchange transfusion. ${ }^{15}$ The present study was undertaken because, in our experience, it was frequently necessary to administer additional calcium at the end of bypass to achieve satisfactory myocardial contractility.

Mannitol in a dose of $1 \mathrm{gm} / \mathrm{kg}$ was added 10 minutes after the start of bypass. Blood losses were replaced in the operating room before and after bypass with ACD blood to which $35 \mathrm{ml}$ of $0.6 \mathrm{M}$ THAM per unit had been added. During bypass the blood loss was replaced with reconstituted ACD blood containing THAM, calcium and heparin in groups $A$ and $B$, and with heparinized blood in group C. In the postoperative period fluid was given as 5 per cent glucose in 0.2 per cent saline in an amount which approximated half the normal maintenance requirements.

\section{Methods}

Blood was drawn from an indwelling arterial cannula into a lightly heparinized syringe at specified times: (1) immediately after induction of anaesthesia; (2) prior to bypass; (3) five minutes after start of bypass; (4) at mid-bypass; (5) just before the end of bypass; (6) after bypass just before the patient left the operating room. Further samples were taken at 4, 8, 20, 24, and 48 hours after the patient had left the operating room.

Blood gas determinations were made immediately using Radiometer $\mathrm{PcO}_{2}, \mathrm{PO}_{2}$ 
and $\mathrm{pH}$ microelectrodes and a PHM 27 meter with gas monitor. The remaining blood was centrifuged anaerobically in the tightly capped syringe at 2500 rpm for 5 minutes and the plasma aspirated anaerobically into a $1 \mathrm{ml}$ tuberculin syringe, sealed with paraffin and frozen.

Determinations of calcium ion activity were made on fresh or frozen plasma samples using a flow-through electrode system. ${ }^{10 *}$ Total calcium and magnesium concentrations in plasma were determined by emission and atomic ab. sorption flame spectrophotometry, respectively. ${ }^{17,18}$ Unknown samples were bracketed between adjacent standard runs. Total protein concentrations in plasma were estimated by the Lowry et al..$^{10}$ procedure, using human serum albumin as the standard and inorganic phosphorus was determined by the Gomori method, ${ }^{20}$ both methods having been adapted to the Autoanalyzer.

Urine collections were carried out during bypass and for 48 hours after the procedure, at 4-hourly intervals for the first 24 hours and at 8-hourly intervals during the second day. The specimens were analyzed for calcium and magnesium concentrations after suitable dilution using the techniques mentioned for plasma determinations.

\section{Results}

Tables III to V summarize the mean ( $\pm \mathrm{SEm}$ ) for blood and plasma values in the three groups of patients.

\section{A. Haematocrit and Plasma Protein Concentrations}

The haematocrit was reduced to the expected degree of 30 per cent in all patient groups when one compares the "early-bypass specimen" with that taken at induotion of anaesthesia. Table VI gives the mean ratios of these two values. A comparable degree of haemodilution was achieved in the three groups despite the relatively wide range of the weights and estimated blood volume of the patients. Plasma protein concentrations were also decreased to a roughly comparable degree, although in group A the protein concentrations were depressed more than the haematocrit and in group $C$ less. No significant differences were detected between groups in the pre-bypass and postoperative haematocrit and plasma protein levels. During bypass in all groups a gradual increase of haematocrit and plasma protein concentrations occurred, but again no differences were seen between groups.

\section{B. Blood $p H$}

Initial post-induction values of $\mathrm{pH}$ were very similar between the groups and the decrease to the "early bypass specimen" was also similar, the mean change in each group being $-0.07 \mathrm{pH}$ units. By the end of bypass, some degree of alkalosis was observed. No differences in $\mathrm{pH}$ values were seen between groups postoperatively, although in most patients a tendency to alkalosis persisted throughout the period of observation.

-Orion Research Inc, 11 Blackstone St., Cambridge, Mass. 02139, U.S.A. 


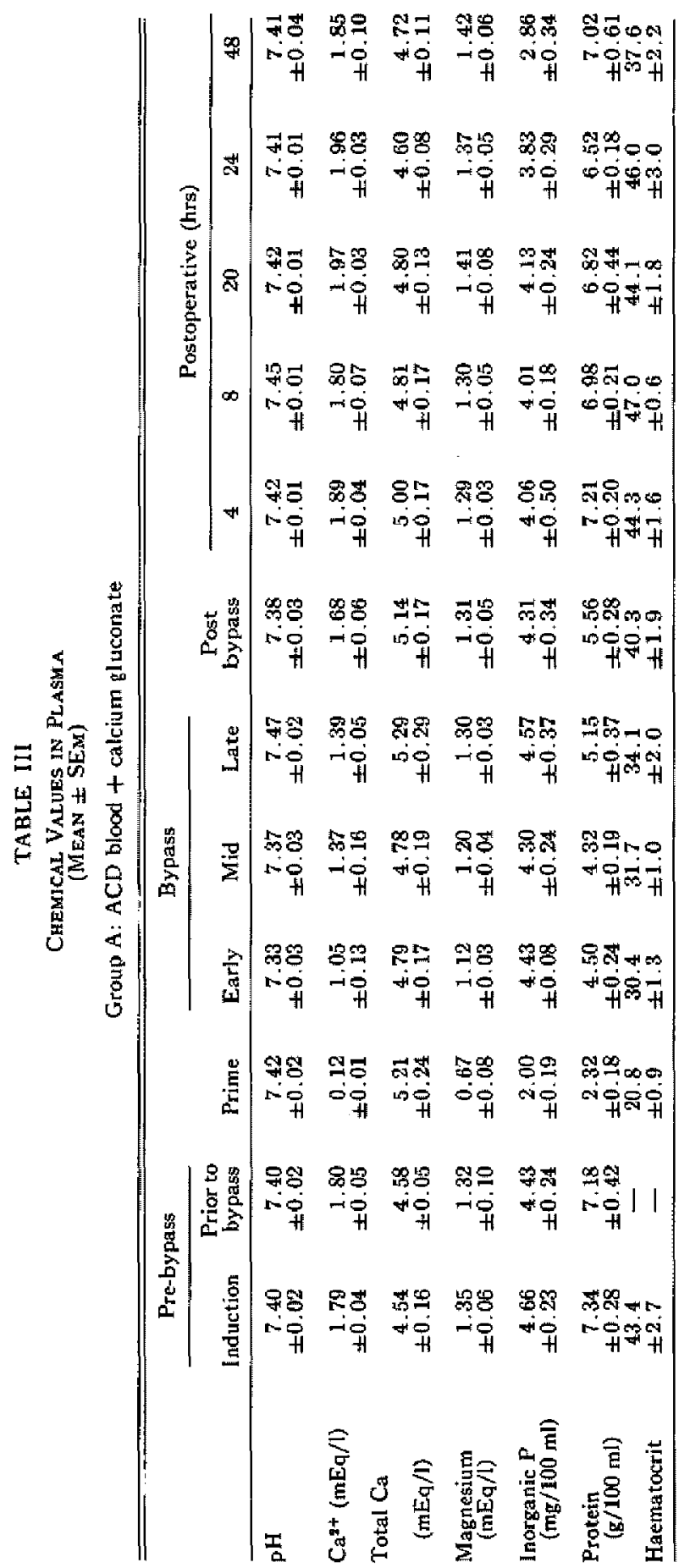




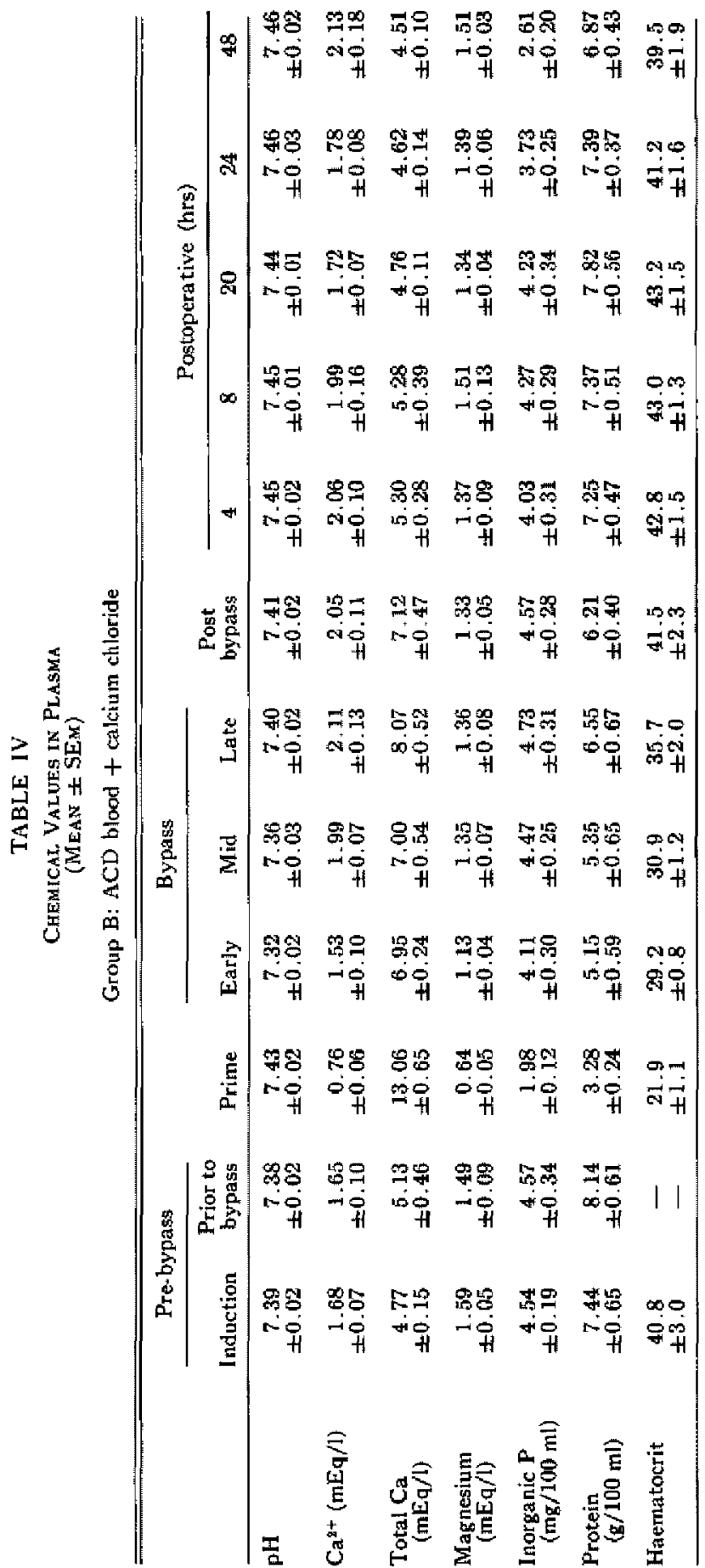




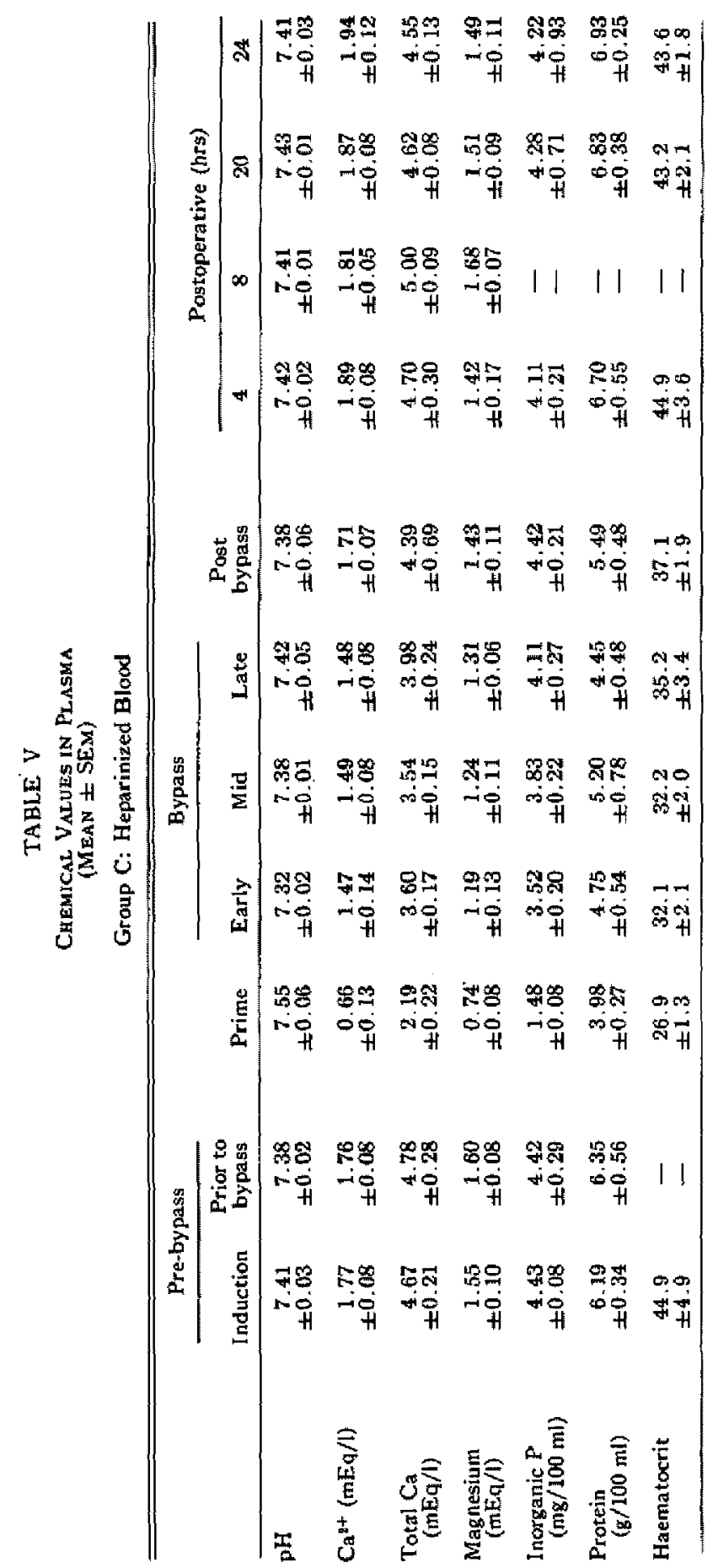


TABLE VI

Ratios of "EARLY-Bypass VaLues"

Values in Brackets = Ratio in Percent of Induction Value

\begin{tabular}{|c|c|c|c|c|c|c|}
\hline & Haematocrit & $\begin{array}{c}\text { Total protein } \\
\mathrm{g} / 100 \mathrm{ml}\end{array}$ & $\begin{array}{c}\mathrm{Ca}^{2+} \\
\mathrm{meq} / 1\end{array}$ & $\begin{array}{c}\text { Total Ca } \\
\text { meq } / 1\end{array}$ & $\underset{\mathrm{meq} / 1}{\mathrm{Mg}}$ & $\mathrm{pH}$ \\
\hline Group A & $\frac{30.4}{43.4}$ & $\frac{4.50}{7.34}$ & $\begin{array}{r}1.05 \\
1.79 \\
(58.6)\end{array}$ & $\begin{array}{r}4.79 \\
4.54 \\
(105.5)\end{array}$ & $\begin{array}{r}\frac{1.12}{1.35} \\
(83.0)\end{array}$ & $\frac{7.39}{7.40}$ \\
\hline Group B & $\frac{29.8}{40.8}$ & $\begin{array}{r}\frac{5.15}{7.44} \\
(69.2)\end{array}$ & $\begin{array}{r}1.58 \\
1.68 \\
(91.1)\end{array}$ & $\begin{array}{r}6.95 \\
\frac{6.77}{(145.7)}\end{array}$ & $\begin{array}{r}\frac{1.09}{1.19} \\
(71.59 \\
(71.1)\end{array}$ & $\frac{7.32}{7.39}$ \\
\hline Group C & $\begin{array}{l}\frac{26.9}{44.9} \\
(71.5)\end{array}$ & $\begin{array}{r}4.75 \\
6.19 \\
(76.7)\end{array}$ & $\begin{array}{r}\frac{1.47}{1.77} \\
(83.1)\end{array}$ & $\begin{array}{r}3.60 \\
4.67 \\
(77.1)\end{array}$ & $\frac{1.19}{1.55}$ & $\frac{7.99}{7.39}$ \\
\hline
\end{tabular}

\section{Plasma Calcium Ion Activity}

In all patient groups the mean ionized calcium values were below the normal range of values $(1.9-2.3 \mathrm{meg} / 1)$ before bypass (Figure 1) and no difference between the post-induction sample and that taken before bypass was found. We have no explanation for this initial low value. The ionized calcium activity of the haemodiluted prime of patients in group A was almost unmeasurable, but was also reduced in primes used in patients of groups $B$ and $C$, although not out of proportion to the degree of haemodilution (Table VI). During the bypass procedure, ionic calcium in the patients" plasma remained low in groups $A$ and $C$ whereas half the values were within the normal range in group $B$.

Clinically, the period between end of bypass and closure of the chest is of great importance because myocardial contractility has to be restored and because our experience has shown that additional calcium had to be administered frequently to patients in both groups $\mathrm{A}$ and $\mathrm{C}$. In each patient two blood specimens were drawn and when tabulated (Table VII) all patients of groups A and

TABLE VII

InCidence of Hypocalcaemia (Ionic Fraction) and Hypomagnesaemia During late Bypass Until Clostre of Chest

\begin{tabular}{lccc}
\hline & Group A & Group B & Group C \\
\hline Decreased Ca & $17 / 17$ & $5 / 20$ & $10 / 10$ \\
ion activity & $(100 \%)$ & $(25 \%)$ & $(100 \%)$ \\
Decreased magnesium & $14 / 17$ & $13 / 20$ & $7 / 10$ \\
& $(83 \%)$ & $(65 \%)$ & $(70 \%)$ \\
\hline
\end{tabular}

$\mathrm{C}$ had plasma calcium ion activity below the normal range, whereas only $5 / 20$ of the samples from patients in group B were within that category.

Postoperatively most of the patients in groups $\mathrm{A}$ and $\mathrm{C}$ remained hypocalcaemic throughout the period of observation, as far as the ionic fraction is concerned, 

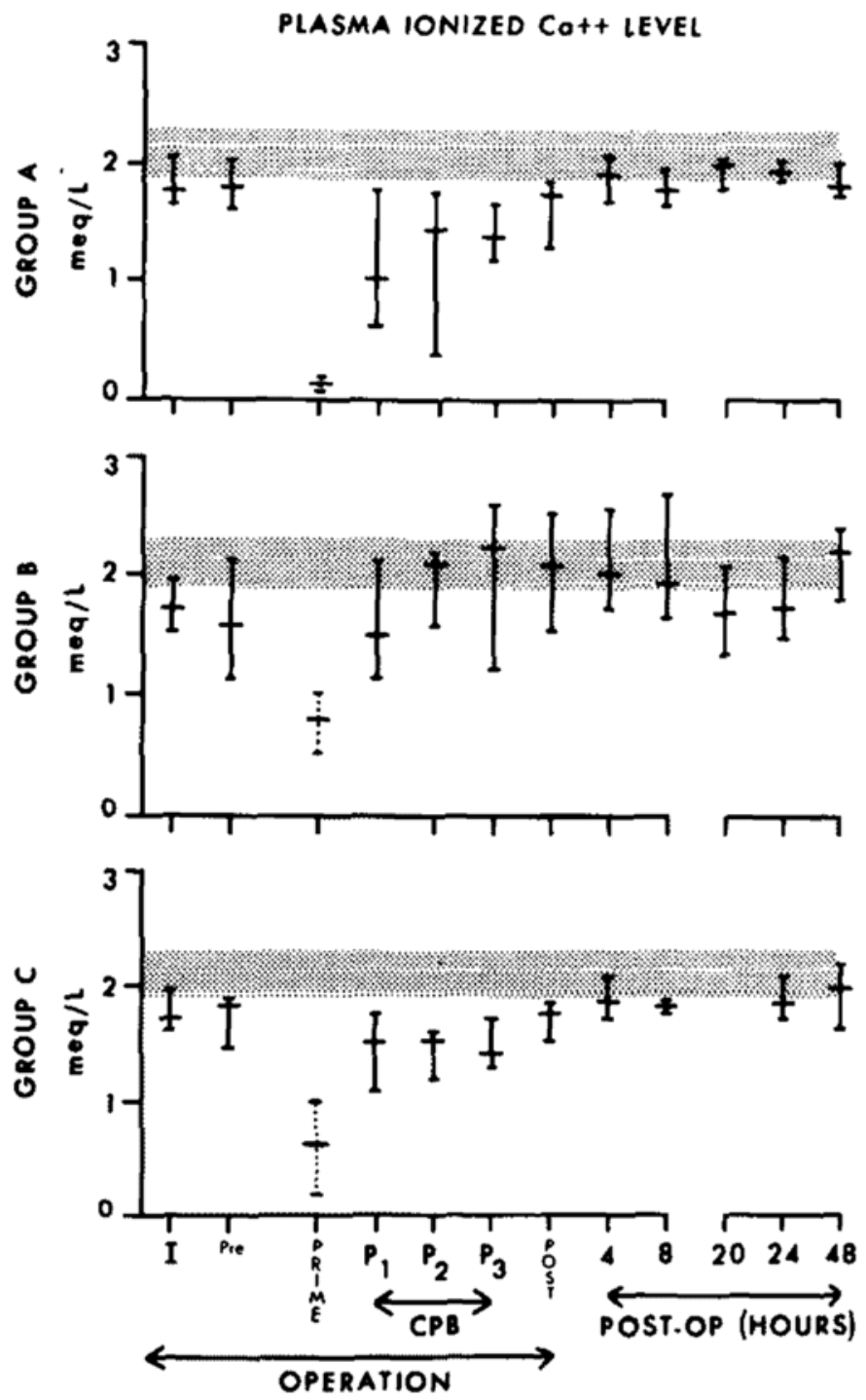

Ficure 1. Plasma calcium ion activity (meq/1) (median \pm range). Shaded areas indicate the normal range. $I=$ specimen taken at induction; Pre $=$ specimen taken inmediately before $C P B$.

although most had higher levels than those found at induction. In group B the mean values were within the normal range on the first day and higher than at induction in most patients, but by the second postoperative day the majority of patients in this group had also become hypocalcaemic. 


\section{Total Calcium Concentrations}

Total calcium concentrations in plasma of patients of all three groups before bypass were somewhat lower (Figure 2) than the mean values obtained with the same method reported in the literature. ${ }^{17}$ Calcium levels in the priming fluids differed widely between the groups. Whereas they were nearly normal in the haemodiluted prime in group A, those of group B were higher and in group $\mathrm{C}$ they were depressed to a degree comparable to that of haemodilution. These differences were reflected in the patients blood during bypass. Patients of group A showed generally steady total calcium levels during the procedure, whereas those of group B were hypercalcaemic and those of group C hypocalcaemic. Postoperatively, plasma values returned rapidly to ranges seen before bypass with half of the patients of groups $A$ and $C$ showing some degree of hypocalcaemia.

\section{E. Plasma Magnesitum Concentrations}

Pre-pump plasma magnesium concentrations were at the lower limit of the normal range (Figure 3). In the priming fluids the magnesium concentrations were decreased to levels consistent with the degree of haemodilution; no differences were observed between the groups. During the operation all patients became hypomagnesaemic to roughly the same degree. At the end of the operation hypomagnesaemia was still observed in the majority of patients of all groups (Table VII). However, since no magnesium has been added to the ACD blood in which the citrate will chelate magnesium ions as well as calcium ions, we presume that all patients of groups A and B were significantly bypomagnesaemic as far as the ionic fraction is concemed.

Postoperatively in group A half the patients still had plasma magnesium levels below the lower limit of normal and in group B only a few values were within the normal range between 20 and 48 hours after operation. The pattern in group C was similar to that in group B, except that postoperatively more patients in group $\mathrm{C}$ had normal values.

\section{F. Inorganic Phosphate Concentrations in Plasma}

In spite of low inorganic phosphate concentrations in the perfusion prime, plasma levels of inorganic phosphate remained unchanged during operation and for the first 24 hours thereafter. In the 48-hour samples both groups with ACDblood-containing prime developed marked hypophosphataemia, whereas the patients receiving heparinized blood remained normophosphataemic.

\section{G. Urine}

\section{Volume}

Urinary output $(\mathrm{ml} / \mathrm{kg} / \mathrm{hr})$ was higher during operation in group B than in groups $A$ and $C$ (Table VIII). When the volume of urine excreted from the start of bypass until 4 hours postoperatively was expressed as a proportion of the volume of the diluent added to the prime, group B excreted an amount equal to the diluent during this time, whereas groups $A$ and $C$ excreted only $\%$ and $r$ of the volume, respectively. The period from start of bypass until 4 hours post- 

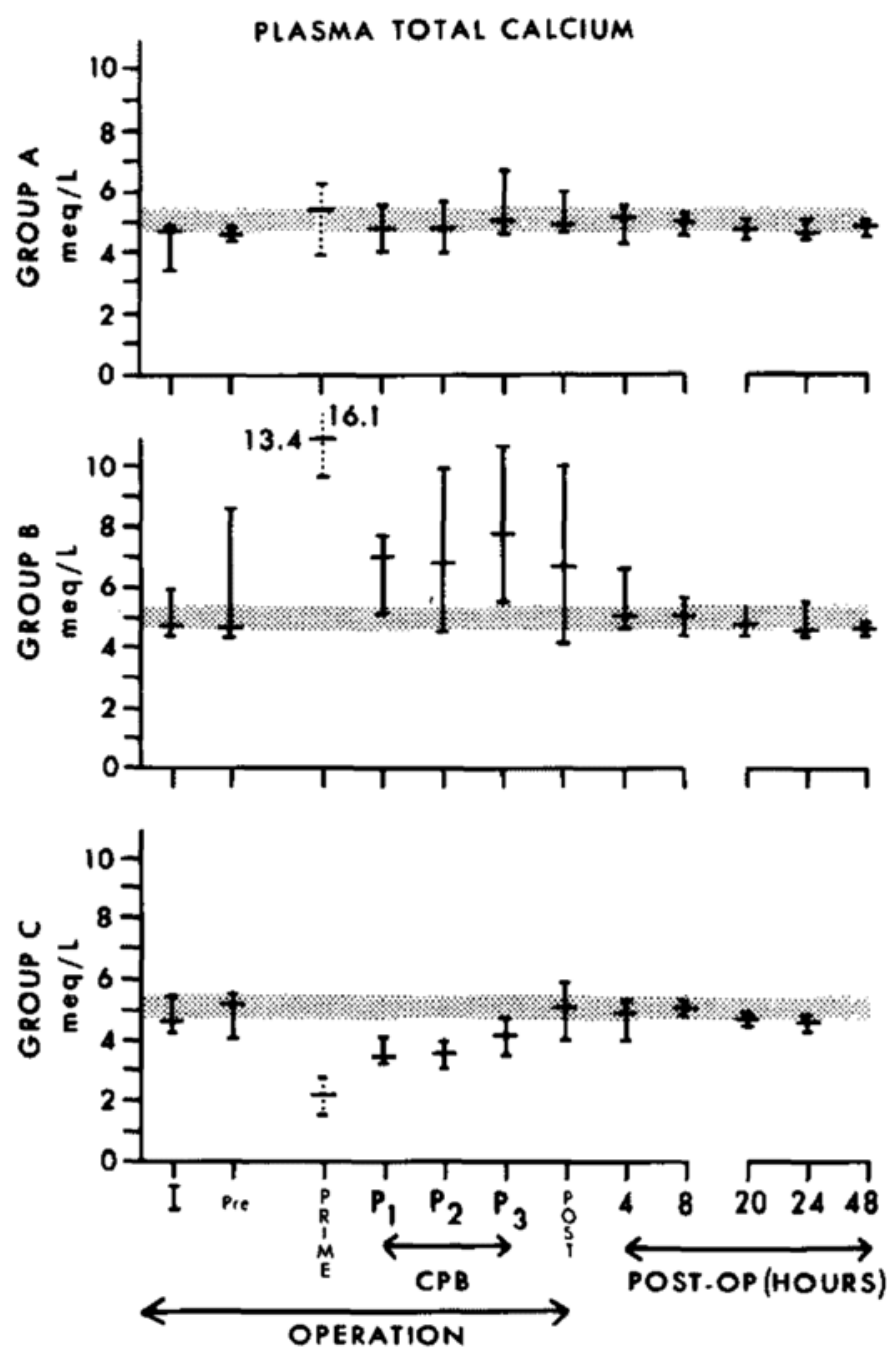

Ficure 2. Plasma concentrations of total calcium (meq/1) (median \pm range). Shaded areas indicate the normal range. $\mathrm{I}=$ specimen taken at induction; Pre $=$ specimen taken immediately before CPB.

operatively was chosen because the initial diuresis was usually over at this time. Patients in group $\mathrm{C}$ showed a brisk diuresis during the remainder of the first postoperative day. During the second postoperative day no differences in urinary volumes were seen between the three groups. 

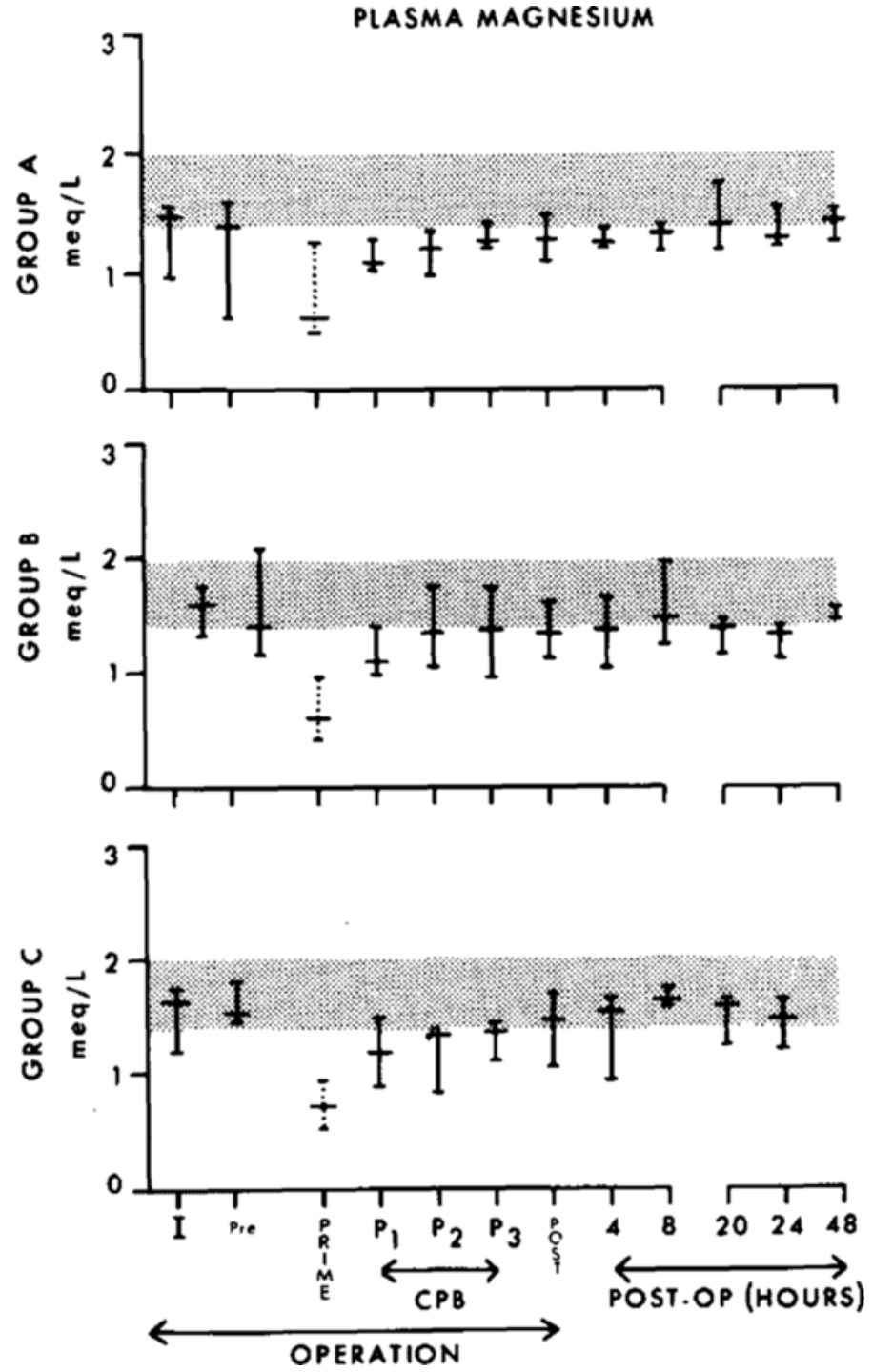

Figune 3. Plasma concentrations of total magnesium (meq/1) (median \pm range). Shaded areas indicate the normal range. $\mathrm{I}=$ specimen taken at induction; Pre = specimen taken immediately before $\mathrm{CPB}$ 
TABLE VIII

URINARY OUTPUT

(MEAN \pm SEM)

\begin{tabular}{|c|c|c|c|c|c|}
\hline & \multicolumn{3}{|c|}{$(\mathrm{In} \mathrm{ml} / \mathrm{kg} / \mathrm{h})$} & \multicolumn{2}{|c|}{$\begin{array}{l}\text { Urinary output as \% of diluent } \\
\text { added to the prime }\end{array}$} \\
\hline & $\begin{array}{l}\text { Start of CPB to } \\
4 \text { hours postop. }\end{array}$ & $\begin{array}{l}\text { 4-24 hours } \\
\text { postop. }\end{array}$ & $\begin{array}{l}24-48 \text { hours } \\
\text { postop. }\end{array}$ & $\begin{array}{l}\text { Start of CPB to } \\
\text { end of operation }\end{array}$ & $\begin{array}{l}\text { Start of CPB to } \\
4 \text { hours postop. }\end{array}$ \\
\hline $\begin{array}{l}\text { Group A } \\
\text { Group A } \\
\text { Group C }\end{array}$ & $\begin{array}{l}4.00 \pm 0.34 \\
5.74 \pm 0.33 \\
3.46 \pm 0.52\end{array}$ & $\begin{array}{l}1.28 \pm 0.10 \\
1.15 \pm 0.12 \\
2.29 \pm 0.44\end{array}$ & $\begin{array}{l}1.63 \pm 0.22 \\
1.87 \pm 0.25 \\
1.82 \pm 0.20\end{array}$ & $\begin{array}{l}52 \pm 6 \\
74 \pm 6 \\
27 \pm 4\end{array}$ & $\begin{array}{r}77 \pm 7 \\
101 \pm 5 \\
45 \pm 5\end{array}$ \\
\hline
\end{tabular}

2. Magnesium and Calcium Excretion

Patients in group B excreted significantly more calcium and magnesium than patients in groups $\mathrm{A}$ and $\mathrm{C}$ during operation and during the first four postoperative hours (Table IX). However, in the 24-48-hour postoperative period their magnesium excretion rates fell to below that of the other two groups. Calcium excretion in patients of group B was higher during operation and during the first postoperative day and lower than the other two groups during the second postoperative day.

TABLE IX

Divalent Catron Excretion in Urine

IN $\mathrm{ME} Q / \mathrm{KG}$

(MEAN \pm SE)

\begin{tabular}{lccc}
\hline & $\begin{array}{c}\text { Start of CPB to } \\
\text { 4 hours postop. }\end{array}$ & $\begin{array}{c}\text { 4-24 hours } \\
\text { postop. }\end{array}$ & $\begin{array}{c}24-48 \text { hours } \\
\text { postop. }\end{array}$ \\
\hline Ca & & & \\
Group A & $0.090 \pm 0.013$ & $0.034 \pm 0.015$ & $0.084 \pm 0.031$ \\
Group B & $0.179 \pm 0.031$ & $0.060 \pm 0.012$ & $0.064 \pm 0.024$ \\
Group C & $0.028 \pm 0.012$ & $0.030 \pm 0.012$ & $0.092 \pm 0.032$ \\
$M g$ & & & \\
Group A & $0.080 \pm 0.018$ & $0.079 \pm 0.016$ & $0.253 \pm 0.046$ \\
Group B & $0.100 \pm 0.017$ & $0.074 \pm 0.014$ & $0.148 \pm 0.032$ \\
Group C & $0.059 \pm 0.020$ & $0.086 \pm 0.038$ & $0.233 \pm 0.050$ \\
\hline
\end{tabular}

\section{Discussion}

The method of calculating the degree of haemodilution was effective as shown by the remarkable constancy of the change in haematocrit and plasma protein in the early bypass specimen compared to induction values. This allows comparison between groups of patients having relatively wide ranges of age, weight and estimated blood volume.

The significant bypocalcaemia in terms of ionic fraction which developed in the patients whose haemodiluted pump prime contained ACD and calcium gluconate in the recommended dosage emphasizes the fact that the amounts of calcium added were insufficient to overcome the calcium-chelating effect of the citrate, although they were sufficient to compensate for haemodilution as evidenced by the normal total calcium values. Similar conclusions were reached 
during exchange transfusion when $\mathrm{ACD}$ blood has been used and calcium gluconate was administered by push injection. ${ }^{8,21}$

The amount of calcium chloride added, although causing marked hypercalcaemia in terms of total calcium was insufficient to overcome completely the citrate chelation as the decrease in calcium ion activity in plasma of most patients of group B showed. Our studies agree with those of Perkins et al. ${ }^{7}$ who observed similar calcium ion activity and total calcium concentration with the addition of $0.6 \mathrm{~g}$ calcium chloride $(6 \mathrm{ml}$ of 10 per cent solution) to 1 unit of ACD blood. The hypercalcaemia (total $\mathrm{Ca}$ ) observed, when calcium chloride in amounts used by other investigators ${ }^{4,5}$ was added to the haemodiluted prime, lasted only until the end of the operation and half the patients developed hypocalcaemia postoperatively.

Using blood collected in heparin solution also led to decreases in calcium ion activity. As the depression of ionized calcium in the early bypass specimens of group $\mathrm{C}$ is slightly less than either the degree of haemodilution or of total calcium depression, we presume that this discrepancy may reflect the mean $\mathrm{pH}$ change from 7.39 to $7.32 .^{22}$ In the other two groups this slightly higher calcium ion activity due to the decrease in $\mathrm{pH}$ is overshadowed by the chelating effect of the citrate and the addition of calcium salts.

In assessing the potentially harmful effects of calcium changes in plasma during bypass, experimental evidence indicates that the hypercalcaemia (total $\mathrm{Ca}$ ) may be less harmful than the hypocalcaemia of the ionic fraction. Since the classic experiments of Ringer ${ }^{23}$ and MacLean and Hasting ${ }^{24,25}$ it is known that the myocardium contracts poorly or not at all when the isolated heart is perfused with calcium-free solutions. Experimental hypocalcaemia leads to a decreased breakdown of high energy phosphates which might account for poor cardiac contractility. ${ }^{20} \mathrm{~A}$ further adverse effect of hypocalcaemia has been reported by Weiss et al. ${ }^{27}$ who perfused hearts with $0.125 \mathrm{mM}$ calcium and rapidly produced a unique form of myofibrillar damage associated with irreversible depression of contractility and excitability. A further mechanism by which hypocalcaemia may produce poor cardiac contractility could be that low external calcium concentrations adversely affect intracellular potassium concentrations of the myocardium. ${ }^{28}$ Lee et al.$^{29}$ studying the effect of extracellular calcium ion activity on reversible cardiac arrest found the heart could be arrested by removing calcium from the extracellular space without changing the $\mathrm{K}^{+}$concentration in the perfusate. Conversely, administration of $\mathrm{K}^{+}$to the patient could conceivably aggravate the potential effects of hypocalcaemia. Increasing the extracellular calcium concentration, on the other hand, does not affect myocardial function adversely until very high levels are reached. ${ }^{11}$

In addition to the effects of calcium ions on myocardial contractility and excitability, its membrane stabilizing effect may account for findings in other organs. Thus, the number of circulating calcium ions will determine water and ion permeability of the kidney. ${ }^{30,31}$ Calcium ions affect water permeability of the nephron opposite in direction to that of anti-diuretic hormone (ADH), both agents acting on the distal but not on the proximal convoluted tubule. However, this calcium ion effect was seen mainly when calcium concentrations in the glomer- 
ular filtrate' were very high (i.e. $>15 \mathrm{meq} / 1$ ). Hypercalcaemia leads to increased excretion of water and sodium. ${ }^{31}$ This diuretic and natriuretic effect will be advantageous in patients undergoing cardiopulmonary bypass. In fact the measured urinary sodium excretion of patients in group $B$ was higher than that seen in patients of groups $\mathrm{A}$ and $\mathrm{C}$. The membrane stabilizing effect of normal or increased calcium ions in the extracellular fluid is reflected in the decreased excretion rates of magnesium postoperatively in patients of group B. Although urinary magnesium losses increased slightly in these patients during operation, presumably due to saturation of reabsorptive pathways for divalent cations, urinary magnesium excretion was significantly lower during the second postoperative day than in the other two groups. The observed normomagnesaemia during the second postoperative day in patients of group B may be a consequence of the lower urinary magnesium excretion.

Another example of the membrane-stabilizing effect of calcium is the observation that increases in ionic calcium in haemolyzing media reduce the degree of hypotonic haemolysis of human erythrocytes. ${ }^{32}$ This effect might be used to advantage in CPB to reduce intraoperative haemolysis.

Derangements of magnesium homeostasis in the postoperative period have been described. ${ }^{33,34}$ Hypomagnesaemia may occur whenever intake is severely curtailed or absorption from the intestine is decreased. Hypomagnesaemia can also occur with increased losses through the kidney, prolonged feeding with magnesium-free intravenous solutions, and in exchange transfusions with ACD blood due to the chelation of magnesium ions by excess citrate. ${ }^{*}$ There are a number of conditions in which intracellular magnesium depletion exists in the presence of normal plasma magnesium concentrations. ${ }^{35}$ Signs and symptoms associated with hypomagnesaemia are: neuromuscular irritability, including tetany and convulsions, decreased muscle tone, both of the smooth and skeletal musculature, hallucinations, cardiac dysfunction and others. ${ }^{36} \mathrm{~A}$ further consequence of magnesium deficiency may be depletion of intracellular potassium concentrations. ${ }^{37.38}$

In our experience, plasma magnesium levels were decreased postoperatively in more than half the patients in all three groups, and although it was not measured, it is probable that ionic magnesium is severely decreased in groups A and B in which ACD blood is being used in the pump prime.

In view of the important role of magnesium ions in energy metabolism, it seems advisable to add magnesium as well as calcium to the haemodiluted pump prime whenever ACD blood is being used. In newborm infants we observed signs and symptoms attributable to hypocalcaemia and/or hypomagnesaemia much more frequently if the product of calcium ion activity (meq/1) $\times$ total magnesium concentration (meq/1) in plasma was less than 1.8 than when it was above this value. ${ }^{39}$

Theoretically, heparinized blood would be the preferred type of blood to be used in the prime and indeed it is the custom at the Hospital for Sick Children to use this blood for children under $10 \mathrm{~kg}$ body weight. However, the observed hypocalcaemia (ionic fraction) and hypomagnesaemia occurring in all samples taken at the end of bypass and until closure of the chest and the similar incidence 
of poor myocardial contractility in this group as compared to that of patients of group A make it doubtful that any advantages accrue from the use of this type of blood. Thus, with the addition of suitable amounts of $\mathrm{CaCl}_{2}$ and $\mathrm{MgCl}_{2}$ to buffered ACD blood, this blood should be suitable for all age groups. We are presently studying the effect of magnesium-containing diluting fluids for the pump prime.

\section{SUMMary}

Divalent cation concentration ( $\mathrm{Ca}^{++}, \mathrm{Mg}^{++}$) in plasma and their urinary excretion rates were measured during and for 48 hours following cardiopulmonary bypass in children undergoing open-heart operations. The patients were assigned to three treatment groups depending on the priming fluid used: ACD blood + calcium gluconate or calcium chloride and heparinized blood. The diluent in each case was 5 per cent dextrose in 0.2 per cent sodium chloride.

Calcium gluconate in the prime failed to provide sufficient calcium ions to overcome the calcium-chelating effect of the citrate. The use of heparinized blood also led to decrease in plasma levels of both ionic and total calcium and of total magnesium but not out of proportion to the degree of haemodilution.

Total calcium levels were high when the prime contained ACD blood and calcium chloride, normal when it contained $A C D$ blood and calcium gluconate and low when it contained heparinized blood.

The hypercalcaemia in terms of total calcium in patients receiving ACD blood with $\mathrm{CaCl}_{2}$ led to the expected increased secretion rates of calcium and magnesium during bypass, but was also followed by decreased excretion rates of the two ions (compared to the other two patient groups) in the second 24-hour period of observation.

We advocate the routine addition of $5 \mathrm{ml}$ of 10 per cent calcium chloride per unit of $A C D$ blood as it minimizes the adverse effects of low ionized and high total calcium. When heparinized blood is used in the haemodiluted prime, calcium chloride ( $1 \mathrm{ml}$ of 10 per cent $\mathrm{CaCl}_{2}$ per unit of blood) should be added. Addition of magnesium salts may also be beneficial.

\section{RÉSUMÉ}

Chez des enfants soumis à des opérations à coeur ouvert, nous avons mesuré, au cours de l'opération et durant les quarante-huit heures après la circulation extra-corporelle (C.E.C.), les taux de cations divalents ( $\mathrm{Ca}+, \mathrm{Mg}^{+}$) dans le plasma de même que leur taux d'excrétion urinaire. Les malades étaient soumis à trois groupes de traiternents différents selon la composition du fluide employé pour amorcer la pompe: soit du sang citraté avec dextrose et du gluconate de calcium (ACD) ou du chlorure de calcium $\mathrm{Ca} \mathrm{Cl}_{2}$ et du sang hépariné. Dans chacune des eventualités, le diluant était de la dextrose à 5 pour cent dans du chlorure de sodium 0.2 pour cent $(\mathrm{NaCl}$ )

L'usage du gluconate de calcium pour amorcer la pompe n’a pas réussi à procurer assez d'ions calcium pour vaincre l'effet fixateur du calcium par le citrate. L'usage du sang hépariné a également conduit à une diminution dans le plasma 
des taux de calcium ionisé et total de magnésium total, mais, toutefois, cela est demeuré dans la proportion du degré d'hémodilution.

Les tau i de calcium étaient élevés lorsque le fluide amorceur contenait du sang citr té $(\mathrm{ACD})$ et du chlorure de calcium $\left(\mathrm{Ca} \mathrm{Cl}_{2}\right)$ et normaux lorsque le fluide amorceur contenant du sang citraté $(A C D)$ et du gluconate de calcium et inférieurs à la normale lorsque le fluide amorceur contenait du sang hépariné.

Chez les malades recevant du sang citraté (ACD) contenant du chlorure de calcium ( $\mathrm{Ca} \mathrm{Cl}_{2}$ ), l'hypercalómie totale (Ca total) a produit l'augmentation attendue des taux d'excrétion de calcium $\mathrm{Ca}^{+}$et de magnésium $\mathrm{Mg}^{+}$durant le temps de la circulation extra-corporelle, mais elle produit, également au cours de la deuxième période de 24 heures d'observation, une diminution de taux d'excrétion des deux ions (en comparaison avec les deux autres groupes de malades).

Nous préconisons l'addition de routine de $5 \mathrm{ml}$ de chlorure de calcium $\mathrm{Ca} \mathrm{Cl}_{2}$ a 10 pour cent pour chaque bouteille de sang citraté (ACD) car ce geste diminue les effets indésirables d'un taux de calcium ionisé plutôt bas et d'un taux de calcium total plutôt élevé. Si l'on emploie du sang hépariné dans le fluide amorceur dilué, il faut ajouter du chlorure de calcium $\left(\mathrm{Ca} \mathrm{Cl}_{2}\right)$ ( $1 \mathrm{ml}$ de chlorure de calcium $\mathrm{Ca} \mathrm{Cl}_{2}$ à 10 pour cent pour chaque bouteille de sang). Il peut également être avantageux d'ajouter des sels de magnésium.

A la suite de l'usage des techniques d'hémodilution chez les malades soumis à des opérations à cceur ouvert avec circulation extra-corporelle, ${ }^{1-5}$ on a observé de multiples écarts de l'équilibre de cation, toutefois, on a rapporté peu d'altérations concernant le calcium ioniséét, ${ }^{i, 7}$ ou le magnésium ionisé, particulièrement lorsque un grand volume de sang citraté et de dextrose étaient employés comme amorceurs de la pompe chez les enfants. Cela revêt un aspect spécial à cause des effets fixateurs du citrate sur les deux ions calcium et magnésium ${ }^{8,9} \mathrm{Ce}$ sont les taux de calcium et de magnésium ionisés qui influencent leur effet sur la stabilité de la membrane cellulaire, sur la contractilité du myocarde et sur le système nerveux central et périphérique aussi bièn que sur la musculature lisse et squelettique. ${ }^{10-14}$

La présente etude traite des changements plasmatiques et urinaires des cations divalents survenant chez les enfants soumis à une opération à cœur ouvert avec circulation extra-corporelle où l'amorceur a été du sang citraté ACD ou du sang hépariné dilués avec glucose 5 pour cent dans du chlorure de sodium 0.2 pour cent.

\section{ACKNOWLEDGMENTS}

The authors acknowledge with gratitude the coroperation of Dr. William T. Mustard, M.D., F.R.C.S.(C), F.A.C.S., Associate Professor of Surgery, University of Toronto, Chief of Cardiovascular Surgery, The Hospital for Sick Children, Toronto; and Dr. George Trusler, M.D., F.R.C.S.(C), F.A.C.S., Assistant Professor of Surgery, University of Toronto, Cardiovascular Surgeon, The Hospital for Sick Children, for allowing us to carry out these measurements on their patients.

The authors also acknowledge with gratitude the assistance and co-operation of Miss Patricia Morrison, R.N., Assistant O.R. Supervisor in charge of Cardio- 
vascular Surgery and her Nursing Staff; and Mr. Jamie Villemater R.N. in charge of the Extra Corporeal Circulation Unit; and the Nursing Staff in the Intensive Care Unit, The Hospital for Sick Children, Toronto.

\section{AEFERENCES}

1. Linder, E., Sakat, Y., \& Paton, B.P. Electrolyte changes durring dilution perfusion. Arch. Surg. 88: 175 (1964).

2. Lockey, E., Longmore, D.B., Ross, D.N., \& Stunamog, M.F. Potassium and open-heart surgery. Lancet 1: 671 (1966).

3. Sesslen, A.D., TAswell, H.F., Mofrit, E.A., \& Kinklin, J.W. Heparinized blood versus ACD blood for cardiopulmonary bypass. Mayo Clin. Proc. 40: 859 (1965).

4. Moffirt, E.A., MaHer, F.T., \& KinkLiN, J.W. Effect of cardiopulmonary bypass and hemodilution on some constituents of blood. Can. Anaesth. Soc. J. 12: 458 (1965).

5. Mofetrt, E.A., Rosevear, J.W., \& McGoon, D.C. Myocardial metabolism in children having open-heart surgery. JAMA $211: 1518$ ( I970).

6. Das, J.B., Eraklis, A., Adams, J.G. Jr., \& Gross, R.E. Changes in serum ionic calcium during cardiopulmonary bypass. J. Thorac. Cardiovasc. Surg. 62: 449 (1971).

7. Perkins, H.A., SNYmer, M., Thacher, C., \& Rolfs, M.R. Calcium ion activity during rapid exchange transfusion with citrated blood. Transfusion 11; 204 (1971).

8. Fafquhan, J.W. \& SMITH, H, Clinical and biochemical changes during exchange transfusion. Arch, Dis, Child, 33: 142 (1958)

9. Bajpai, P.C., Denton, R.L., Harpur, E., Stern, L., \& Sugden, D.L. The effect on serum ionic magnesium of exchange tranşfusion with citrated as opposed to heparinized blood. Can. Med. Assoc. J. 96: 148 (1967).

10. WhItTAM, R. \& WhEsLEn, K.P. Transport across cell membranes. Ann. Rev. Psysiol. 32; $21(1970)$.

11. LeE, Y.C.P., Richman, G., \& Visschen, M.B. $\mathrm{Ca}^{++}$and $\mathrm{K}^{+}$interrelations influencing mechanical and electrical events in cardiac activity. Am. J. Physiol. 210: 499 (1966).

12. Entman, M.L. Calcium and cardiac contractility. Am. J. Med, Sci. 259: 164 (1970),

13. Walsen, $M$. Magnesium metabolism. Ergeb. Physiol. 59: 185 (1965).

14. ENGBAEK, L. The pharmacological actions of magnesium ions with particular reference to neuromuscular and cardiovascular system, Pharmacol, Rev. 4: 396 (1952).

15. Sherman, I., Alpenstein, B.B., \& Sherman, B.K. Intravenous calcium gluconate as aid in reduction of post-transfusion reaction. NY State J. Med, 43: 2419 (1943).

16. Radoe, I.C., Höfrken, B., \& Parkinson, D.K. Practical aspects of a measurement technique for calcium ion activity in plasma. Clin. Chem. 17: 1003 (1971)

17. Macint Yhe, I. Flame photometry. Adv, Clin. Chem. 4; 1 (1961).

18. Alcock, N., MacINTYAE, $I$, \& RADDE, I. The determination of magnesium in biological Huids and tissues by flame spectrophotometry. J. Clin. Pathol, 13: 506 (1960).

19. Lowhy, O.H., Rosebrough, N.J., Fanh, A,I, \& Rantal.l, R.J. Protein measurement with the folin phenol reagent. J. Biol. Chem. 193: 265 (1951).

20. Gomoru, G. A modification of the colorimetric phosphorus determination for use with the photoelectric colorimeter. J. Lab. Clin. Med, 27: 955 ( I942).

21. Frifdman, A., Hankey, W.B., \& RaDDE, I.C. Ionized calcium in exchange transfusion with ACD blood. Can. Med. Assoc. J. (to be published).

22. HöfFken, B., Parkinson, D.K., Storms, P., \& Radne, 1.C. Effects of alterations of blood $\mathrm{pH}$ on calcium ion activity in rat plasma. Clin. Orthop. 78: 30 (1971).

23. Runcer, S.A. A further contribution regarding the influence of the different constituents of the blood on the contraction of heart. J. Physiol. 4: 29 (1883).

24. McLean, F.C. \& Hastings, A.B. The state of calcium in the fluids of the body. I. The conditions affecting the ionization of calcium. J. Biol. Chem. 108: 285-322 (1935).

25. McLfax, F.C. \& Hastrings, A.B. Clinical estimation and significance of calcium-ion concentrations in the blood. Am. J. Med. Sci. 189: 601 (1935).

26. Sckmloner, F.W. \& FuEckenstrin, A. Die Bedeutung der extracellulären Calciumkonzentration fitr die Spaltung von energiereichem Phosphat in ruhendem und tätigem Myocardgewebe. PAluegers Arch. 283: 137 (1965)

27. Werss, D.L., Surawrcz, B., \& Rubinstan, I. Myocardial lesions of calcium defieiency causing irreversible myocardial failure. Am. J. Pathol. 48 : 653 (1966). 
28. GuMORE,' J.P., Daccetr, W.M., McDonatd, R.H., \& SARNofF, S.J. Influence of calcium on myocardial potassium balance, oxygen consumption, and performance. Am. Heart J. 75: 215 ( 1968 )

29. LeE, Y.C., Richman, H.G., \& Vtsschent, B. Exeracellular calcium ion activity and reversible cardiac arrest. Am. J. Physiol. 210: 493 (1966).

30. Lassrren; W.E., FHick, A., Rumaich, G., \& ULl.uch, K.J. Influence of ionic calcium on the water permeability of proximal and distal tubules in the rat kidney. Pfluegers Arch. 285: 90 (1965)

31. FulGrafF, G. \& Himenrejch, $O$. Mikropurkkionsuntersuchungen über die Wirkung von Calciumionen aut die Resorptionskapazitat und auf die prozentuale Resorption im proximalen Konvolut von Ratten. Naunyn Schmiedebergs Arch. Pharmakol. 258: 440 (1967).

32. MANN, J. \& CoLLER, H.B. The effect of calcium ion on hypotonie hemolysis of human erythrocytes. Life Sci, 8: 1343 (1969).

33. SAwYen, R.B., Drew, M.A., Gesinx, M.H., SAwYer, K.C. JR., \& SAwYer, K.C. Postoperative magnesium metabolism. Arch. Surg, 100:343 (1970).

34. Sмrrн, W.O. Magnesium deficiency in the surgical patient. Am. J. Cardiol, 12: 667 (1963).

35. Butzer, A.M. Diabetic coma. N. Engl. I. Med. 243: 648 (1950).

36. WACKen, W.E.C. \& VALLEE, B.L. Study of magnesium metabolism in acute renal failure employing multichannel flame spectrometer. N. Erigl. J. Med. 257; 1254 (1957).

37. Cotrove, E., Holliday, M.A., SchWartz, R. \& Wallace, W.M. Effects of electrolyte depletion and acid-base disturbance on muscle cations, Am. J. Physiol, 167: 665 (1951).

38. Paunieh, L., Radde, E.C., Koon, S.W., Conen, P.E., \& Frasen, D. Primary hypomagnesemia with secondary hypocalcemia in an infant. Pediatrics 41 : 385 (1968).

39. Radde, I.C., Parkinson, D.K., Hörfiken, B, Appiah, K.E., \& Hanley, W.B. Calcium ion activity in the sick neonate: effect of bicarbonate administration and exchange transfusion. Pediatr. Res. 6: 43 (1972). 